\title{
Phlebia cremeoalutacea new to Finland and new records of rare corticioid fungi (Basidiomycota)
}

\author{
PANU KUNTTU, TIMO KOSONEN, MATTI KULJU and HEIKKI KOTIRANTA
}

\begin{abstract}
KUNTTU, P., KOSONEN, T., KULJU, M. \& KOTIRANTA, H. 2009: Phlebia cremeoalutacea new to Finland and new records of rare corticioid fungi (Basidiomycota). - Karstenia 49: 69-71. Helsinki. ISSN 0453-3402.

Phlebia cremeoalutacea is reported as a corticioid fungus new to Finland. New records of Colacogloea peniophorae, Trechispora invisitata ssp. hauerslevi and Trechispora laevis are given. All these records were made in SW Finland, from the forested islands of the Archipelago Sea. Inventories were carried out between July and November 2008. As Phlebia cremeoalutacea is known to inhabit especially the hemiboreal zone and it has been found from all the other countries adjacent to Finland, its discovery can be considered as expected. The three other species are little collected, with less than five earlier records.
\end{abstract}

Key words: Archipelago Sea, Colacogloea peniophorae, corticioid fungi, Phlebia cremeoalutacea, Trechispora invisitata ssp. hauerslevi, Trechispora laevis

Panu Kunttu, University of Joensuu, Faculty of Forest Sciences, P.O. Box 111, FI-80101 Joensuu, Finland; e-mail: panu.kunttu@joensuu. $f$ i

Timo Kosonen, Herbarium, University of Turku, FI-20014 Turku, Finland; e-mail: tikoso@utu.fi

Matti Kulju, Ylispuuntie 13, FI-90420 Oulu,Finland; e-mail: m.kulju@kolumbus.fi

Heikki Kotiranta, Finnish Environment Institute, P.O. Box 140, FI-00251 Helsinki, Finland; e-mail: heikki.kotiranta@ymparisto.fi

\section{Introduction}

In this paper, one corticioid species is reported as new to Finland, and new records of three rarely collected fungi in Finland are presented. All the records were made in SW Finland, on the forested islands of the Archipelago Sea, part of the Northern Baltic Sea. The main purpose of this study was to increase the knowledge on the communities of the aphyllophoroid species in the area.

Biogeographically the Archipelago Sea is interesting, being at the southernmost part of the Finnish coast line. It belongs to the hemiboreal zone (Ahti et al. 1968) and consists of thousands of islands ranging from small skerries to relative large islands of several hundreds of hectares in size. Herb-rich forests are common and some of the smaller islands are nearly pristine, whereas on larger islands traditional land use has changed the landscape substantially. In essence, the archipelago region has a high biological diversity because of the large variety of habitats (Lindgren et al. 2001).

The recent check-list of Finnish aphyllophoroid fungi (Kotiranta et al. 2009) lists altogether 980 species from Finland. The coastal region of southwestern Finland, including the Archipelago Sea, is a very species rich area: 752 aphyllophoroid species are known to exist in the region (Kotiranta et al. 2009). The only existing publication on its fungal flora, a survey published by Vauras (2000), is focused on Agarics but lists also some aphyllophoroid species. So far, no 
large scale systematic field studies have been carried out concentrating on wood-decaying fungi in this area.

\section{Materials and methods}

Panu Kunttu (PK) and Timo Kosonen (TK) surveyed polypores and corticioid fungi on the Archipelago Sea between July 15th and November 16th in 2008. Fifteen islands were inventoried, and altogether 1148 specimens were collected. The corticioid specimens were identified mainly by Matti Kulju (MK) and Heikki Kotiranta (HK).

Finnish national uniform grid system $\left(27^{\circ} \mathrm{E}\right)$ according to Heikinheimo and Raatikainen (1981) was used for coordinates. All the collections were made from the hemiboreal zone in the biological province of Regio aboënsis $(\mathrm{Ab})$. Voucher specimens are deposited in the herbarium of the University of Turku (TUR). The Finnish national evaluation of IUCN Red List Categories is according to Rassi et al. (2001). Decay stage of the trunks is according to Renvall (1995). Nomenclature follows Kotiranta et al. (2009).

\section{Results and discussion}

Phlebia cremeoalutacea (Parmasto) K.H. Larss. \& Hjortstam

Specimens examined: Finland. Regio aboënsis, Kemiönsaari, Dragsfjärd, Södra Benskär (Grid $27^{\circ} \mathrm{E}$ 6658:3237) 30.VII.2008 PK 2988, det. MK, conf. HK 2009. Fruit body grew on a broken and fallen Pinus sylvestris "kelo" (barkless) trunk. The trunk measured $13.5 \mathrm{~m}$ in length and $18 \mathrm{~cm}$ in diameter at breast height (DBH). The trunk was still fairly hard (decay stage 2) and Skeletocutis amorpha had grown on the same trunk.

The areal of the relatively rocky island is circa 25 hectares. A substantial part of the forested area is pine dominated fairly barren forest. The other main tree species is Alnus glutinosa, dominating the shore line and the lush depressions.

Even though described already in 1968, and the new combination made in 1977, the distribution and ecology of Phlebia cremeoalutacea is still poorly known (Parmasto 1968, Hjortstam $\&$ Larsson 1977). It has been found from Norway, Sweden, Denmark, Estonia, Germany and Carpathian mountains and from a few places in Russia (Altai, Siberia) (Hjortstam \& Larsson 1977, Eriksson et al. 1981, Hansen \& Knudsen 1997). In Sweden and Norway it has been found only from the hemiboreal zone and is classified as a rare species. From Denmark it is found only from East Jylland (Hansen \& Knudsen 1997). In Europe $P$. cremeoalutacea grows at least on Pinus, Picea, Alnus and Fagus (Eriksson et al. 1981). Most of the collections derive from coniferous wood (Hjortstam \& Larsson 1977).

Colacogloea peniophorae (Bourdot \& Galzin) Oberw., R. Bauer \& Bandoni

Specimens examined: Finland. Regio aboënsis, Kemiönsaari, Dragsfjärd, Kuggskär (Grid $27^{\circ} \mathrm{E}$ 6638:3240), 1.X.2008 PK 4041, det. HK 2009. The substrate was a broken and fallen, $2.9 \mathrm{~m}$ long, relatively highly decayed (stage 4) trunk of Alnus glutinosa with the DBH of $19 \mathrm{~cm}$. It grew on the same trunk together with Gloiothele citrina in herb-rich forest.

The four earlier records of $C$. peniophorae from Finland are all from the hemiboreal zone Länsi-Turunmaa (Houtskär and Parainen), Turku and Hanko). The new record is the southernmost. Colacogloea peniophorae is a fungal parasite and found on trunks of Corylus, Quercus and Pinus, in all cases interhymenial on Peniophorella praetermissa (Kotiranta et al. 2009).

Although G. citrina grew on the same trunk, C. peniophorae seemed to grow without a host species. At least no fruitbody of $P$. praetermissa was visible.

The habitats in Finland are herb-rich forests and dry heath forests (Kotiranta et al. 2009). Colacogloea peniophorae is assigned to the least concern (LC) category. In Denmark this species is common in the whole country (Hansen \& Knudsen 1997). In Norway it occurs in hemiboreal and boreal zones (Akershus-Oslo \& NordTrøndelag) and in Sweden it is occasional in the temperate, hemiboreal and boreal zones (Hansen \& Knudsen 1997). In Finland it is most probably a common species, since the host is one of the most common corticioids in Finland. The current knowledge of the distribution is insufficient, and the species can be expected to grow also much further northwards. Many corticiologists, especially in earlier days, did not pay attention to "infected" specimens, and these were seldom preserved in herbaria.

Trechispora invisitata ssp. hauerslevi (H.S. Jacks.) Liberta

Specimens examined: Finland. Regio aboënsis, Kemiönsaari, Dragsfjärd, Vänö (Grid $27^{\circ} \mathrm{E}$ 6649:3230), 15.XI.2008 $P K$ 4497, mesic herb- 
rich forest, on broken, fallen, $4.5 \mathrm{~m}$ long, much decayed (decay 4) Alnus glutinosa, $34 \mathrm{~cm}$ in diameter, together with Amphinema byssoides and Haplotrichum conspersum, and Dragsfjärd, Kuggskär (Grid $27^{\circ} \mathrm{E}$ 6638:3240), 29.IX.2008 $P K 4040 a$, grass-herb forest, on partly corticated, $10 \mathrm{~cm}$ thick, much decayed (decay 4) trunk of A. glutinosa, det. MK, conf. HK 2009.

The three earlier records of T. invisitata from Finland are from the hemiboreal or south boreal zones (Länsi-Turunmaa: Parainen, Hämeenlinna: Lammi, and Muurame). These new records are the southernmost. Previous habitats have been mesic heath forests and dry and mesic herb-rich forests. All the records in Finland are from strongly decayed trunks of Betula or Picea (Kotiranta et al. 2009). The species is reported to grow on small woody debris, on ferns, leaves and mosses (Kotiranta et al. 2009). In Europe it has been found at least from Denmark and Sweden (Hjortsam et al. 1998). In Finland T. invisitata is assigned to the least concern (LC) category. Microscopically the new specimens agree with that reported by Kotiranta and Saarenoksa (2000).

Trechispora laevis K.H. Larss.

Specimens examined: Finland. Regio aboënsis, Länsi-Turunmaa, Parainen, Kuggö (Grid $27^{\circ} \mathrm{E}$ 6680:3231), 12.X.2008 TK 653-2008, det. MK \& HK 2008. The substrate was a broken, fallen, relatively strongly decayed (decay 3 ) trunk of $P i$ cea abies, $12 \mathrm{~cm}$ in diameter, together with Conferticium ochraceum and Hyphodontia breviseta in mesic heath forest.

There are four earlier records from Finland, from the hemiboreal or south boreal zones Länsi-Turunmaa: Parainen, Helsinki, Hämeenlinna: Lammi, and Padasjoki). This new record is the southernmost (Kotiranta et al. 2009). The main habitats in Finland are mesic heath forests, some of them old-growth. Trechispora laevis has been assigned as least concern (LC).

\section{References}

Ahti, T., Hämet-Ahti., L. \& Jalas, J. 1968: Vegetation zones and their sections in northwestern Europe. - Annales Botanici Fennici 5: 169-211.

Eriksson, J., Hjortstam, K. \& Ryvarden, L. 1981: Corticiaceae of North Europe 6: 1102-1104. - Fungiflora. Oslo.

Hansen, L. \& Knudsen, H. 1997 (eds.): Nordic macromycetes 3. Heterobasidioid, aphyllophoroid and gastromycetoid basidiomycetes. - Nordsvamp. Copenhagen. 444 pp.

Heikinheimo, O. \& Raatikainen, M. 1981: Ruutukoordinaattien ja paikannimien käyttö Suomessa. - Notulae Entomologicae 61: 133-154.

Hjortstam, K. \& Larsson, K.-H. 1977: Notes on Corticiaceae (Basidiomycetes). - Mycotaxon 5: 475- 480.

Hjortstam, K., Larsson, K.-H. \& Ryvarden, L. 1988: Corticiaceae of North Europe 8: 1504-1505. - Fungiflora. Oslo.

Kotiranta, H. \& Saarenoksa, R. 2000: Corticioid fungi (Aphyllophorales, Basidiomycetes) in Finland. - Acta Bot. Fennica 168: 1-55.

Kotiranta, H., Saarenoksa, R. \& Kytövuori, I. 2009: Aphyllophoroid fungi of Finland. A check-list with ecology, distribution, and threat categories. - Norrlinia 19: 1-223.

Lindgren, L., von Numers, M. \& Hæggström, C.-A. 2001: Saariston arvokkaat maabiotoopit. - In: von Numers, M. (ed.): Saaristoympäristöt - nykytila, ongelmat ja mahdollisuudet: 147-160. Nordiska Ministerrådets Skärgårdssamarbete, Turku. 252 pp.

Parmasto, E. 1968: Conspectus systematis corticiacearum. - Inst. Zool. Acad. Scient. R.P.S.S. Estonicae. Tartu. $262 \mathrm{pp}$.

Rassi, P., Alanen, A., Kanerva, T. \& Mannerkoski, I. (eds.) 2001: Suomen lajien uhanalaisuus 2000. - Ympäristöministeriö \& Suomen ympäristökeskus, Helsinki. $432 \mathrm{pp}$

Renvall, P. 1995: Community structure and dynamics of wood-rotting Basidiomycetes on decomposing conifer trunks in northern Finland. - Karstenia 35: 1-51.

Vauras, J. 2000: Saaristomeren kansallispuiston suursienet. - Metsähallituksen luonnonsuojelujulkaisuja A 112: 1-91. 